\title{
THE RIGHT TO EDUGATION IN THE SYSTEM OF THE CONSTITUTIONAL RIGHTS OF UKRAINE (COMPARATIVE ANALYSIS)*
}

\author{
Olga MELNICHUK** \\ Maxim MELNICHUK***
}

\begin{abstract}
SUMMARY: I. Introduction. II. Place of the right to education in the system of constitutional rights. III. Correlation between the right to education and the right to dignity. IV. Interaction of the right to education and the right to freedom of creativity. V. Correlation of rights: to education and to free personal development. VI. Interaction of rights: to education, to freedom of thought and speech, to free expression of views and beliefs, to information. VII. Relationship between the right to education and the right to work. VIII. Interaction of rights: to education and social protection.

IX. Conclusions. X. Bibliography.
\end{abstract}

\section{INTRODUCTION}

The state's guarantee of the right to education is of great importance for the development of an individual and a society. After all, an effective realization of this right ensures satisfaction of human needs in acquiring knowledge, forming skills, abilities, personal qualities and other competencies. The right to education is the basis for the implementation of a whole range of other constitutional rights. It provides a person with a high standard of living, respect and dignity, the development of creative abilities, the choice of profession, comprehensive and harmonious development, etcetera. This

* Artículo recibido el 9 de noviembre de 2017 y aceptado para su publicación el 18 de julio de 2018 .

** ORCID: 0000-0003-4229-621X. Doctor of law sciences, associate professor, dean of the Department of Management and Law, Vinnytsia National Agrarian University, Ukraine. Correo electrónico: Melnychuk.o.f@gmail.com. Google Scholar: https://scholar.google. com.ua/citations?'user $=X q H_{-} z 5$ IAAAAJEhl=uk.

*** ORCID: 0000-0001-9196-8751. Candidate of law sciences, senior lecturer of the Department of Law, Vinnytsia National Agrarian University, Ukraine. Correo electrónico: Melnychuk.m.o@gmail.com.

Boletín Mexicano de Derecho Comparado, nueva serie, año LI, núm. 154, enero-abril de 2019, pp. 539-568.

Esta obra está bajo una Licencia Creative Commons Atribución-NoComercial-SinDerivar 4.0 Internacional, IIJ-UNAM. 
right is aimed at ensuring the full functioning of state and public institutions, national security, it strengthens stability in society and promotes the development of a democratic, social and constitutional state.

Determining the place and role of the right to education in the system of constitutional rights is of paramount importance as it promotes understanding of its essence and peculiarities, helps to establish ties between groups of rights and to identify common and different in these categories, provides the expansion of cognitive abilities, etcetera.

The right to education closely interacts with other rights that a person owns, being in a close dialectical relationship. The role of the right to education in the system of other constitutional rights is highly appreciated by scientists. In particular, T. Matyusheva notes that the right to education is a kind of right-guarantee. Realization of this legal possibility is closely linked with significant achievements in raising the legal security of an individual as a whole. Only qualitative education will allow a person, after obtaining it, not to depend on other circumstances and along with economic independence will create more complete guarantees of satisfaction of individual interests (Matyusheva, 2008: 2).

The literature recognizes that the right to education is a key tool that helps to realize other constitutional rights, the "core" of human rights (Motakef, 2006). This statement is substantiated by a number of reasons. First, the right to education, by arming a person with a certain level of competence, ensures an effective realization of electoral law, participation in political activity, promotes establishment and development of democracy in society, transfer of knowledge, skills and abilities to future generations in order to live. Secondly, without education, a person does not develop as an individual and can not realize his potential. Thirdly, the right to education ensures the welfare of a person, satisfies his needs in food, health, housing and labor. But the most important thing is that it ensures development of human dignity. According to K. Dieter (2006: 26-28), the last two characteristics of the analyzed law are significant evidence that the human right to education must be recognized as a fundamental right.

Indeed, there is a close interaction between the right to education and other constitutional rights, which is expressed in their interdependence, the guarantee of one right to another. Usually, this relationship is so strong that it is sometimes impossible to give preference to one of the rights by defining the level of performance of the warranty mission to the other.

Esta obra está bajo una Licencia Creative Commons

Atribución-NoComercial-SinDerivar 4.0 Internacional, IIJ-UNAM.

Boletín Mexicano de Derecho Comparado, núm. 154, enero-abril de 2019, pp. 539-568. 
The foregoing indicates the need to reveal the correlation between the right to education and other rights (freedom of creativity, free development of an individual, freedom of thought and speech, free expression of views and beliefs, information). In our opinion, this will help to clarify the essence of the right to education, its guarantees of implementation and a role for a particular person and society as a whole.

\section{Place OF THE Right TO EDUCATION IN THE SYSTEM OF CONSTITUTIONAL RIGHTS}

In the legal literature, unambiguous approaches to the basis of the classification of constitutional rights and freedoms are absent. The basis is taken from different criteria, but the most common is the division of rights by the spheres of public life. The authors share the point of view as for appropriateness of such classification and suggest that civil, political, economic, social and cultural rights be to distinguished in the system of constitutional rights, which corresponds to the title of the same name international covenants. Ukrainian scholars most often include the right to education to a group of cultural rights. However, O. Skakun adheres to another opinion and considers it not only cultural but also social right (Skakun, 2001: 178-183). In addition, P. Rabinovich and O. Pankevich, while studying social rights, also refer the right to education to this group (Rabinovich and Pankevich, 2003: 104-107). Moreover, some scholars consider the right to education to be the main social right since through its implementation access to other rights (to work, health, housing, food, etcetera) is ensured (Horbath, n. d.) . The analysis of Russian and Ukrainian studies devoted to this topic does not point to such an unanimity of scholars' views on the definition of the right to education in the system of constitutional rights. By systematizing scientists' views on the identified problem, they can be divided into four groups. According to some of them (Bonyak, 2005: 26-27), the right to education belongs to a group of cultural rights. Others regard it as both cultural and social rights (Romanenko, 2008: 29). Some scholars are inclined to believe that the analyzed right belongs to the category of socio-economic rights (Kalpinskaya, 2005: 27). Sometimes scholars state that the right to education applies to social, economic and cultural rights (Rybakova, 2005: 50; Smirnova, 2011: 30; Tyapkina, 2009: 8). 
In favor of attributing the right to education to cultural rights is evidenced by the fact that encyclopedic and explanatory dictionaries, emphasizing the ambiguity of the notion of culture, highlight its meaning as enlightenment, discretion (Great Dictionary of Contemporary Ukrainian Language, 2002: 472). S. Goncharenko notes that

the educated person is not just a graduate of a school who studied the sciences taught there, but a person capable of empathy, ready for a free humanistic oriented choice, an individual intellectual effort and an independent, competent and responsible action in the political, economic, professional and cultural life. He respects himself and others, tolerates representatives of other cultures and nationalities, is independent in judgments and is open to another judgment and unexpected thought (Goncharenko, 2008: 615-616).

In its turn, discrestion involves culture of feelings, culture of thinking, aesthetic tastes, responsibility of a person, etcetera.

Cultural rights ensure "the preservation and development of national and cultural identity of the people, access to the material and spiritual achievements of mankind, their assimilation, use and participation in the further development of them" (Skakun, 2001: 182) in the interests of an individual, state, and society. They guarantee spiritual development of a person, help each individual to become a useful participant in political, spiritual, social and cultural progress.

It should be noted that the right to education occupies a prominent place among cultural rights, since one of its functions is the transfer of material and spiritual culture to the next generations, its reproduction and development. In our view, the right to education is related to cultural rights due to its characteristics, such as the development of creative potential of person, knowledge and self-knowledge of society, social groups, a individual, the transfer of social information, experience, and creation of value landmarks for a person in the society. Consequently, the "cultural" content of the right to education is obvious, so we consider it lawful to assign the right to education to a group of cultural human rights.

As to the belonging of the right to education to a group of social rights, only a small number of native scholars attribute this opportunity to a defined group of rights. The opposite trend is observed in Russian literature, and this discourse leads to the need of finding out the right to education among the category of social rights. In order to determine

Esta obra está bajo una Licencia Creative Commons

Atribución-NoComercial-SinDerivar 4.0 Internacional, IIJ-UNAM.

Boletín Mexicano de Derecho Comparado, núm. 154, enero-abril de 2019, pp. 539-568. 
this place, we first study out the concept of social rights. Scientists define social rights such as "consist in acquiring social benefits, possession, use and disposal of them and their protection or certain actions in this area" (Pustovit, 2003: 560), as "recognized by the constitution of human rights for material, and sometimes, spiritual support from the state, rarely - other persons in order to ensure decent conditions for material, physiological and moral existence" (Alebastrova, 2010: 31). Among the existing definitions, we are most impressed with the following:

Social rights are the ability of a person to ensure his/her existence and development out of social sources through social dependence, that is, on the basis of the social and alimentary methods applied by certain conditions (at the onset of so-called social risks) by state or non-governmental organizations regulation (Rabinovich and Pankevich, 2003: 205).

In our opinion, this concept allows us to distinguish social rights from others, because it absorbs certain features of this group of rights. It is observed that social rights can be distinguished by means of such a feature as social dependence, which involves social support of a person at the expense of state or local budgets.

As noted, sometimes the right to education is reffered to an independent group of economic rights. And this is not a coincidence, because culture and economy are closely interconnected. M. Smirnova quite rightly believes that education is a branch of the economy (Smirnova, 2006: 32). According to Mrs. Rybakova, combining the right to education with the economic rights such its property as an opportunity of a person to master a profession, which creates conditions for financial security. On the other hand, realization of the right to education requires material expenses of a state or a person himself (Rybakova, 2005: 50).

Looking for the truth in the legality of assigning the right to education to a group of economic rights, in our opinion, it is advisable to move away from understanding the essence of the latter. For this purpose, we use the research of Y. Frolova, who notes that economic rights are "provided by the Constitution and laws of Ukraine possibility of certain behavior in the economic sphere" (Frolov, 2005: 169). According to the scientist, it becomes clear that economic rights are realized in the sphere of the economy, which is known to consist of material and non-material production. 
Therefore, economic rights can be defined as a human capacity to own, use, and dispose of major economic (material and non-material) benefits and to acquire means of subsistence and development.

For a long time, the sphere of non-material production was considered necessary, but not productive as for creation of a new cost in it, national income. However, in this area, services are produced that have a consumer value, that is, they are goods (Martynyuk et al., 2001: 511). And just the sphere of services includes educational ones.

A number of objective reasons led to the emergence and development of the science of complex economic role of education in the process of expanded reproduction, in particular the reproduction of economic relations-education economics. These should include: formation of educational system as an independent and specific branch of the economy; deployment of scientific and technological revolution, which resulted in an essential expansion of education, a significant increase in the cost of it, strengthening of the impact of education on the rate of economic growth; aggregate contribution of education to growth of future incomes of society as a whole and an individual in particular in the scope of $75-80 \%$, establishment of the size of wages and its differentiation, depending on the complexity of the workforce, its general education and qualification levels (Economic Encyclopedic Dictionary, 2005: 185). According to the UNESCO International Statistical Institute, each additional year of study increases the average income of a person about $10 \%$, and country's GDP by $0.37 \%$ annually. ${ }^{1}$ That is, education is the resource that provides economic development of a state and individual citizens. The above facts indicate that the right to education by such a criterion as a sphere of public relations belongs to a group of economic rights.

The study of research state of the analyzed problem shows that in the foreign literature the right to education is attributed not only to the block of social, economic and cultural rights, but also to the category of civil, political rights and freedoms. ${ }^{2}$ Foreign scholars substantiate their point of view with the fact that this right involves freedom that can be expressed in

1 The number of children who do not attend school is increasing again, especially in Africa (n. d.).

2 Right to Education Indicator based on the 4 A framework. Concept Paper, Prepared by Gauthier de Beco, Independent Consultant for The Right to Education Project (2009: 7).

Esta obra está bajo una Licencia Creative Commons

Atribución-NoComercial-SinDerivar 4.0 Internacional, IIJ-UNAM.

Boletín Mexicano de Derecho Comparado, núm. 154, enero-abril de 2019, pp. 539-568. 
many ways. That is, it is the right of parents to choose educational institutions for their children and provide them with religious and moral education in accordance with their own beliefs, and domination of academic freedom in educational institutions, and keeping the state from further discrimination of students on the basis of race, sex, language, religion or culture and from excessive interference with the right to education (Beiter, 2006: 32).

In our opinion, such considerations of foreign scholars can be explained by a high level of development of the principle of freedom of education in foreign countries. The research conducted by M. Smirnova confirms the development of the tendency to guarantee the principle of freedom in the foreign educational system. The scientist believes that the principle of freedom in education is a common denominator of foreign educational systems, which, along with freedom of religion, freedom of association and freedom of speech, is one of the four pillars of the legal system, political and social organization (Smirnova, 2011: 245-264).

We share the point of view of foreign researchers, the more that the right to education is really significantly linked with the freedom of worldview, spirituality, moral and psychological properties of a person, to some extent brings it closer to civil rights, which are directly aimed at the development and preservation of given qualities. There is also a visible connection of the right to education with political rights, in the sense of the first as a certain basis, subsoil for possible implementation of the latter. However, in our view, one must admit that, nevertheless, the measure of state restriction of freedom in the aspect of the right to education and the level of its state security is more important than civil and political rights, which makes it impossible to attribute this right to the specified classification groups.

\section{Correlation BetweEn the Right TO EDUCATION} AND THE RIGHT TO DIGNITY

International legal acts recognize human dignity as the highest social value. The Universal Declaration of Human Rights proclaims that all people are born equal and free in their dignity and rights; nobody should be subjected to torture or cruel, inhuman or degrading treatment 
or punishment. ${ }^{3}$ The last thesis of the declaration is also enshrined in the Convention for Protection of Human Rights and Fundamental Freedoms (Article 3) and is further extended in the International Covenant on Civil and Political Rights (Article 7).

In the Preamble of the International Covenant on Civil and Political Rights and the International Covenant on Economic, Social and Cultural Rights, the Charter of the United Nations, dignity, together with the inalienable rights, is recognized as the basis of freedom, justice and universal peace. Even more so, in the specified legal acts it is indicated that human rights derive from the inherent dignity of a human person. Thus, human dignity is promoted to the rank of the principle of law. According to M. Bratasyuk, in addition to the mentioned documents, references to the category of human dignity and to it, as a principle, are contained in at least fifty international legal documents adopted by the United Nations (Bratasyuk, 1999: 94).

The content of Articles 3, 21, 28 of the Constitution of Ukraine shows that the international legal thesis regarding dignity of a person are implemented in the basic law of the State. Respect for dignity is guaranteed by the constitutions of such States as Germany (Article 1), Spain (Part 1 of Article 10), Belarus (Article 25), Russia (Article 21).

Despite the widespread use of the category «dignity» in legal acts and scientific literature, its legislative definition is still absent. Characteristically, in non-legal sources of encyclopedic character, emphasis is placed on the moral side of this phenomenon, namely, on the set of features that characterize the moral qualities and awareness of a person of his social importance, public duty (Great Dictionary of Contemporary Ukrainian Language, 2002: 180).

The philosophical, ethical and etymological value of dignity one way or the other is reflected in the legal literature. More often, the views of scholars are reduced to the understanding of dignity as a subjective and an objective phenomenon. In this sense, dignity is understood as «the highest social value, which testifies, from one, objective side, about the significance of a person for society from the standpoint of his moral, spiritual,

3 The Universal Declaration of Human Rights, adopted and proclaimed by Resolution 217 A (III) of the General Assembly of the United Nations of December 10, 1948 (2008).

Esta obra está bajo una Licencia Creative Commons

Atribución-NoComercial-SinDerivar 4.0 Internacional, IIJ-UNAM.

Boletín Mexicano de Derecho Comparado, núm. 154, enero-abril de 2019, pp. 539-568. 
physical (natural) qualities, that is, the importance of an individual as a person, as a representative of mankind independently from his belonging to one or the other social community, group and position in society, and on the other, subjective, side - about an individual significance of a person of his moral, spiritual, physical (natural) qualities, regardless of social affiliation to that or another community of people and position in society, the awareness and sense of importance» (Tserkovna, 2003: 10). According to the author, such an approach is justified, since the restriction of dignity by one of the parties will degrade its content, narrowing the functional purpose. After all, the subjective aspect of dignity performs a motivating function in human behavior, while the objective side of dignity is important in the aspect of protecting the right to human dignity, guaranteed by international legal acts (Kostetska, 2008: 44).

Awareness of a person that he is the highest value causes respect for himself and others, to the existing rights and freedoms. Accordingly, dignity performs a motivational mission in human behavior, induces it to develop, to respect and protect not only its rights and freedoms, but also others. The dialectical combination of the subjective and the objective side of dignity allows, at the level of individual and social consciousness, to recognize the uniqueness, self-worth of a person. Therefore, it is quite legitimate to assume that dignity is the value of a person as such (selfworth), regardless of any biological or social properties (Rabinovich, 2003: 21). In other words, "human dignity is a person himself as the highest value, as an example for other values and their ultimate measure" (Tsomplak, 2012: 17).

We believe that without a recognition of the human right to dignity, the value of the right to education is lost. The relationship between the right to education and the right to dignity is expressed in the social purpose of education, which "must be directed towards the full development of the human person and awareness of his dignity and must strengthen respect for human rights and fundamental freedoms" (International Covenant on Civil and Political Rights, 1995). The right to education is intended to ensure the formation and development of a person's dignity. The implementation of this function is that by gaining new knowledge, forming skills, abilities and certain properties, a person raises the level of self-knowledge and self-esteem, is aware of his significance. Thanks to the mastering of new knowledge and the formation of personal qualities, 
a person "grows" in a qualitative way, which enables him to develop a certain attitude towards himself and others. A personal sense of dignity motivates him/her to improve, predetermines the desire to be better, and forms a striving to bring up human qualities in himself. The moral development of a person is directly proportional to the formation of dignity and perception of each person, regardless of any characteristics, as a unique individual.

The task of education is to educate and develop self-esteem in the learners, that is, the given social phenomenon is called to form the person himself. The functional purpose of education is especially acute in view of the fact that the person who is educated and brought up, for the most part, has the status of a child. Taking children into pre-school or general education institutions, parents entrust child's personality, which is vulnerable and in need of support, to the pedagogical personel.

Each child requires an attitude to himself as to the most valuable creature in the world, so it is important not to degrade his dignity in order not to slow down the development process.

Despite the high mission of the education in the direction of raising a sense of self-dignity, full development of a person, educational sphere has not become the exemplary model. We agree with N. Karpachova that at present a school not only plays an important role in life of children as an environment of basic socialization, but also serves as a place where children often face violence in their lives and this problem is systemic. Among the forms of violence dominate beatings, insults, humiliation, kicking, underarming, use of offensive nicknames, damage to property, deprivation of food and money, unpleasant touches to the body, boycotts, etcetera. The facts of violence against students are not rare; they are accompanied by records on mobile phones, followed by placement them for viewing on the Internet. Such crimes were committed by students in a number of oblasts of Ukraine and Kyiv. Therefore, it seems appropriate for N. Karpachova to borrow foreign experience to combat this brutal phenomenon. This implies the introduction of a ban on filming and spread of violence scenes (with the exception of special editions) on the model of France. For such actionsin this state a penalty of 5 years' imprisonment or a fine of 75 thousand eurosis imposed (Karpachova, 2010: 51-52).

With sadness it is necessary to State that pedagogical workers sometimes act as abusers of schoolchildren. From time to time mass media, 
Internet news report similar facts. For evidence, we present only some of them. So, the prosecutor's office of Zaporizhzhya district of Zaporozhye region filed a criminal case on the grounds of a crime envisaged in Part 1 of Article 125 of the Criminal Code of Ukraine, on the fact of causing light bodily injuries by the teacher of physical training to the student of the ninth grade. ${ }^{4}$

Another, unworthy of teacher's rank case, happened in the secondary school. During a lesson with the sixth grade students, for student's refusal to bring a bucket of water to wash the board, the teacher of labor training first hit the boy on the face, and when the child fell, he kicked him a few times to the side. According to doctors, the child had a subcapsular rupture of the right kidney. ${ }^{5}$

It is believed that the problem of counteracting the application of school violence is relevant not only for Ukraine but also for other countries including Mexico. So, Ursula Zurita Rivera, a professor at the Latin American Faculty of Social Sciences (FLACSO), believes that school violence is manifested through the corporal punishment, sexual and emotional abuse, school harassment (bullying), youth gangs, use of weapons, etcetera (Zurita, 2011).

Various forms of value depreciation of a student's personality, his honor and dignity often become the cause of academic failure, deviations in behavior and even cases of suicide (Rybalka, 2010: 44). Such harassment of children is qualified by the European Court of Human Rights as degrading dignity, that is, "they are intended to cause a victim a sense of fear, suffering and feeling of inferiority, and also to degrade his/her dignity and break his/her physical and moral resistance" (Vdovichenko and Kampo, 2012: 66) That is, the practice of European judicial proceedings testifies about the possibility of judicial protection of the right to dignity.

Consequently, the right to dignity determines the right to education, since it enables to acknowledge a person as the highest social value that needs his development. Namely, the right to education acts as a mean of improvement and self-realization, full development of an individual, strengthening respect of a person, his dignity, rights and fundamental

4 In Zaporozhye, a teacher broke the nose to the 9th grade (n. d.).

5 In Chernivtsi, a teacher who beat a pupil in a classroom, was sentenced to one year imprisonment (n. d.). 
freedoms. Consequently, the right to education forms and develops a sense of dignity both in an individual and in public consciousness.

\section{INTERACTION OF THE RIGHT TO EDUCATION AND THE RIGHT TO FREEDOM OF CREATIVITY}

Given the fact that the right to education is closely linked with the freedom of creativity, there is a need to find out the correlation between them.

The Universal Declaration of Human Rights guarantees every person: the right to freely participate in the cultural life of a society, to enjoy art, to participate in scientific progress and to use its benefits; the right to protect moral and material interests, which is the result of scientific, literary or artistic works, the author of which he/she is. ${ }^{6}$ These principles are reflected in the International Covenant on Economic, Social and Cultural Rights and strengthened by the principle on the obligation of States, participating in the Covenant, to respect the freedom that is indispensable for scientific research and creative activity (International Covenant on Civil and Political Rights, 1995). Based on these documents, the Constitution of Ukraine in Article 54 guarantees citizens the freedom of literary, artistic, scientific and technical creativity, protection of intellectual property, their copyright, moral and material interests arising from various types of intellectual activity; the right to the results of their intellectual, creative activity. Comparison of the principles of the Basic Law and international standards in the field of human rights indicates an unjustified constriction of the subjects of these rights by the Constitution of Ukriane, as well as the types of creativity themselves. In this regard, we consider T. Milov's (2008: 20-23) remarkable comments on the need of improvement of the constitutional norm in the direction of guaranteeing the specified rights not only to citizens but also to everyone, and not only the freedom of literary, artistic, scientific, technical, but also other forms of creativity.

6 The Universal Declaration of Human Rights, adopted and proclaimed by Resolution 217 A (III) of the General Assembly of the United Nations of December 10, 1948 (2008).

Esta obra está bajo una Licencia Creative Commons

Atribución-NoComercial-SinDerivar 4.0 Internacional, IIJ-UNAM.

Boletín Mexicano de Derecho Comparado, núm. 154, enero-abril de 2019, pp. 539-568. 
In the Constitutions of Spain (Article 20), Germany (Article 5), Belarus (Article 51), Russia (Article 44), as well as in Article 17 of the basic law on the general rights of citizens of Austria it is guaranteed not only freedom of scientific creativity, but also freedom of teaching. ${ }^{7}$ Instead, Ukraine is inferior to the indicated states in the constitutional regulation of the right to freedom of teaching. Taking into account the practice of constitutionalism of European states, we propose to lay down Part 1 of Article 54 of the Constitution of Ukraine in the following wording: "Everyone is guaranteed freedom of literary, artistic, scientific and technical creativity, teaching, protection of intellectual property, copyright, moral and material interests arising in connection with various types of intellectual activity".

The constitutional principles analyzed have been reflected in the educational laws of European states. In particular, in $\S 2$ of the Austrian Federal Law "On the organization of universities and study at universities", part 3 of Article 2 Unique (Organic) Law on the Universities of Spain, in Section 4 of the Framework Law on Higher Education in Germany.

The scientific definition of the freedom to creativity is consistent with its international interpretation in the meaning of the cultural ability of a person to engage in literary, artistic, scientific, technical creativity and to possess, dispose and use the results of his creative activity in the form of literary, artistic and industrial property (Oliinyk, 2000: 93).

Expanding the content of the freedom of literary, artistic, scientific and technical creativity, S. Lysenkov concludes that it aims at creating the conditions for the most complete expression of creative abilities and is intended to provide Ukrainian citizens with the opportunity to conduct freely, that is, uncontrolled by the state and other structures, scientific and technical study, literary, artistic and any other creative activity; possibility to use state support in creative activity; the inviolability of copyright, that is, the impossibility of using or disseminating the results of a citizen's creative activity without his consent, except in cases established by law (Lisenkov, 2001: 431-432).

It is well-known that the acquisition of education involves the creative realization of an individual, his participation in scientific research,

7 Educational Legislation of Foreign Countries. Laws of Austria, Great Britain, Spain, China, Mexico, the Netherlands, France (2003: 19). 
constuctive research and development and other types of scientific activities, conferences, competitions, exhibitions, contests, etcetera. So, when entering an educational institution, a person pursues the goal of obtaining education, but, performing the tasks of the curriculum, he/she can simultaneously be realized as an artist, a singer, a scientist, etcetera. To do this, conditions should be created that would guarantee a person freedom to creative activity. Instead, in order to write an artistic work or perform other creative work, one needs to acquire new knowledge, to form certain skills, abilities, personal qualities. In this case, the right to education serves as a means of ensuring the right to creativity.

Literary, artistic, scientific and technical creativity, proceeding within the framework of educational legal relations, differs from that carried out outside of them. First of all, it has an educational purpose: the identification and development of creative abilities in a person who learns, and developing the ability to apply acquired skills in future life. This activity is conducted under the guidance of pedagogical or scientific-pedagogical workers, that is, it is marked by a lower degree of autonomy, compared with creativity realized in other spheres. In addition, one or another educational level defines the requirements for the formation of creative abilities, skills and abilities of the learner,as well as to the novelty of creativity, in particular. That is, they grow in proportion to the increase of educational level, and may also depend on the level of the educational institution. So, higher educational institutions, first of all, provide a person an opportunity to exercise the right to freedom of scientific creativity. Scientific and scientific-technical activity, which is an integral part of higher education, plays a significant role in the development of creative abilities of an individual. Y. Shemshuchenko and T. Milova consider that the activity of higher educational institutions is one of the forms of realization of the right to freedom of scientific creativity (Shemshuchenko and Milova, 2008: 39), which must be agreed upon.

We believe that the conditions for the exercise of the right to freedom of scientific creativity are created not only for the persons who are studying but also for the scientific and pedagogical workers in higher educational establishments. After all, respectively, scientific and scientific-technical activities of teachers are ensured by combining the content of education and scientific activity, implementing the results of scientific research and development, direct participation in research and development work 
carried out in higher educational institutions, organization of scientific, scientific-practical, scientific-methodical seminars, conferences, competitions, etcetera.

Consequently, during the study, we concluded that the freedom of literary, artistic, scientific and technical creativity determines the need for the right to education, which promotes realization of a person as a creative individual. The right to education is intended to create conditions for the identification, formation and development of creative abilities of the learners, as well as their self-realization. And in that, a full realization of the right to education is not possible without the guarantee of freedom of creativity.

\section{CORRELATION OF RightS: TO EDUGATION AND TO FREE PERSONAL DEVELOPMENT}

The right to education is directly linked with one fundamental right - free development of an individual-. According to Article 13 of the International Covenant on Economic, Social and Cultural Rights "Education should be directed towards the full development of a human person..." (International Covenant on Civil and Political Rights, 1995). In addition, this right at the international level is proclaimed by the Declaration on the Right to Development, approved by the United Nations General Assembly on December 4, 1986. By this international act it is recognized as an inalienable right, by virtue of which every person and all peoples have the right to participate in such an economic, social, cultural and political development, in which all human rights and fundamental freedoms can be fully realized, as well as further development and enjoyment of its benefits. The concept of development is defined in the Preamble of the Declaration:

... development is a comprehensive economic, social, cultural and political process aimed at the continuous improvement of the well-being of the entire population and all individuals on the basis of their active, free and constructive participation in development and in the equitable distribution of the benefits they create (Declaration on the Right to Development dated December 4 1986). 
As the document itself States, all aspects of this right are indivisible and interdependent, and each of them should be considered in the context of the whole.

It is important that in the Declaration a person himself is recognized as the main subject of the development process and must be an active participant and beneficiary of this right. Therefore, it is the responsibility of all people to develop individually and collectively, taking into account the need for full respect of human rights and fundamental freedoms, as well as their responsibilities to society, which alone can ensure free and full development of a human person. They should encourage and protect the appropriate political, social and economic order necessary for development. Along with this, the State directly has both the right and the duty to determine a relevant national development policy aimed at the continuous improvement of the well-being of the entire population and all individuals on the basis of their active, free and constructive participation in development and fair distribution of benefits created by them. According to the Declaration, States should take all necessary measures at national level to exercise the right to development and, in particular, ensure equality of opportunity for all in access to basic resources, education, health, food, housing, employment and just distribution of revenues.

The right to free development of a personality is guaranteed in the constitutions of such European States as Spain (Article 10) and Germany (Article 2). According to Article 23 of the Constitution of Ukraine, every person has the right to free development of his/her personality, if this does not violate the rights and freedoms of other people. ${ }^{8}$

In our opinion, the direct effect of education on the development of personality is reflected in the Article 3 of Political Constitution of the Mexican United States, which, in the first place, proclaims the goal of education "the development of all human abilities" (CPEUM). It is through education that the improvement of economic, social, cultural conditions of the people and the nation takes place, and relations between people are improved. Note that the constitutional provisions of the right to education are specified in the Mexican educational law. We refer to the Law on Education (Ley General de Educación) and the Law on Higher Education

8 The Constitution of Ukraine, adopted at the fifth session of the Verkhovna Rada of Ukraine on June 28 (1996)

Esta obra está bajo una Licencia Creative Commons

Atribución-NoComercial-SinDerivar 4.0 Internacional, IIJ-UNAM.

Boletín Mexicano de Derecho Comparado, núm. 154, enero-abril de 2019, pp. 539-568. 
(Ley Sobre Educación Superior), according to which education provides a comprehensive, harmonious development of an individual, contributes to the development of critical thinking, involvement of citizens in public decision-making, and the formation of respect for human rights, including language rights of indigenous peoples, strengthens the rule of law, peace, increases awareness of nationality and sovereignty, and so on.

Close relationship between the right to education and the right to free development of a person is also reflected in the legislation of certain European States. In particular, the educational laws of the German lands guarantee "every young person the right to school education and development" (Thüringer Schulgesetz [ThürSchulG] in der Fassung der Bekanntmachung, 2003). The Code of Education of France sees the main purpose of education as the opportunity for everyone to "develop their personality, raise their level of initial and continuing education, become involved in public and professional life, and fulfill their public purpose" (French Code of Education, 2003).

According to the modern concept, human development is the process of expanding choice for a person. First of all, it is a choice of three important things: to lead a healthy lifestyle and live a long time, gain knowledge, have resources to maintain a decent standard of living. It also includes political, economic and social freedoms, the ability to engage in creative and productive activities, human rights guarantees (Rabinovich, 2001: 111).

Scientists believe that the right to development includes: full sovereignty and independence of a person and social groups in the use of natural resources; self-determination; participation of individuals in development; equality of opportunity; the creation of favorable conditions for the use of civil, economic, social and cultural rights by the State and the international community (Malyarenko, 2010: 279).

The foregoing makes it possible to highlight the most important features of this right, which are the following: 1) the right to development is an inalienable right of every person and all peoples, that is, it is individual and collective at the same time; 2) this right is multifaceted and consists of economic, social, cultural and political development, in which all human rights and fundamental freedoms can be fully realized; 3) provides equality of opportunities for access to basic resources, education, health, nutrition, housing, employment and fair distribution of income; 4) everyone (every person, society and state) should promote development and use 
its benefits; 5) realization of the right to development depends directly on the activity of a person himself, an entire society and a state; 6) all aspects of the right to development are indivisible and interdependent, and each of them should be considered in the context of the whole.

S. Maksimov believes that in the right to free development of a personality are expressed all social rights in general terms. The right to education, being one of them, is logically a part of the right to development (Maksimov, 2009: 406).

To ensure the right to development, there is a need to have equal access to social benefits, including education. In this regard, S. Nazarco points out that "education deepens people's understanding of themselves and the outside world, enriches the mind, broadens experience and improves the choices they make as consumers, producers and citizens. All this, both directly and indirectly, promotes human development" (Nazarco, 2009: 169).

Realization of the right to education opens opportunities for a person and a citizen, aimed at their full development. When entering an educational institution, a person improves his social environment, which enables him to be among the teachers who help to form his own point of view on the world, to create himself/herself. A student is expanding opportunities for communication with peers, making friends, which brings great spiritual satisfaction and growth. A special role in ensuring spiritual and social development of an individual is given to higher education. Realization of the right to higher education creates "a potential opportunity for a person to get into a new social environment, gain a new status and move from low-skilled to higher levels of social structure"; "2.3 times reduces risk of poverty and 1.6 times increases the likelihood of obtaining middle income, greatly affects the way of life" (Nazarco, 2009: 167-168). In general, the right to education, which is designed to meet the needs of a person and a citizen in gaining knowledge, formation of skills, abilities, certain psychological properties, other competences, provides a harmonious development of an individual.

Consequently, we can see that the right to education is an integral part of the right to development. The latter performs a generalizing mission for all social rights, that is, in content broader than the first. The right to education ensures realization of the right to development, that is, it serves as the right-guarantor. 


\section{INTERACTION OF RIGHTS: TO EDUCATION, TO FREEDOM OF THOUGHT AND SPEECH, TO FREE EXPRESSION OF VIEWS AND BELIEFS, TO INFORMATION}

The right to education is closely interrelated with the rights proclaimed in Article 34 of the Constitution of Ukraine - to freedom of thought and speech, free expression of views and beliefs, to information. These rights are also guaranteed by the Constitutions of Belarus (Article 33, Article 34), Russia (Article 29), Spain (Article 20), Germany (Article 5). The content of these rights is based on the principles of international standards. Thus, the Universal Declaration of Human Rights proclaims for everyone the right to freedom of belief and its free expression, including freedom to unobstructedly adhere to one's beliefs and freedom to search, receive and disseminate information and ideas by any means and regardless of state frontiers. ${ }^{9}$ The Convention for the Protection of Human Rights and Fundamental Freedoms guarantees everyone the right to freedom of expression (European Convention for the Protection of Human Rights and Fundamental Freedoms: Implementation in Ukraine 2006). This right includes the freedom to follow one's beliefs, receive and transfer information and ideas without interference by public authorities and regardless of frontiers. Article 19 of the International Covenant on Civil and Political Rights specifies the right to unobstructedly adhere to one's views, stating that this right includes the right to search, receive and transfer any information and ideas, regardless of state borders, orally, in writing, by printing or artistic expressions, or by any other means by own choice (International Covenant on Civil and Political Rights, 1995).

In our view, important is also the norm in Part 3 of Article 19 of the International Covenant on Civil and Political Rights, Part 2, Article 10 of the Convention for the Protection of Human Rights and Fundamental Freedoms, which imposes restrictions to freedom of thought and expression, free expression of views and beliefs, information

in the interests of national security, territorial integrity or public security, in order to prevent disturbances or crimes, to protect health or morals, to pro-

9 The Universal Declaration of Human Rights, adopted and proclaimed by Resolution 217 A (III) of the General Assembly of the United Nations of December 10, 1948 (2008). 
tect the reputation or rights of others, to prevent a disclosure of confidential information or to maintain the authority and impartiality of the court. ${ }^{10}$

It is important that the case-law of the European Court indicates the application of the principles of Article 10, Part 2 of the Convention for the Protection of Human Rights and Fundamental Freedoms, in order to protect "the Little Red Textbook" from the harmful influence on the morals of children and adolescents. In its judgment, the Court explains that this book includes sentences and paragraphs that young people in the turning point of their development could construe as encouragement to actions that do not correspond to their age and are harmful to them or even to commit certain criminal offenses (Jenis et al.,1997: 158).

Scientists believe that the meaning of freedom of thought and speech lies in the fact that no one can forbid people to follow their thoughts, in some way reflect the objective reality in their representations and publicly express these materialized in the language of reflection, in particular views and beliefs. The latter may apply to all areas: foreign policy, state power, economic processes, education and culture, the development of legislation, etcetera (Rabinovich and Havronyuk, 2004: 158).

When expressing their thoughts on guaranteeing the right to freedom of thought and speech, researchers make proper explanations. First, the commented order does not concern any thought, but only that which has already been expressed outward, objectified by some physical behavior. Thus, the right of a person to free expression of his thoughts is authorized, in particular those which are views, beliefs. Secondly, since in addition to views and beliefs there are also other forms of thinking, the considered freedom is related to expression of its other "products": rationalized feelings, attitudes, orientations, concepts, theories, etcetera. Thirdly, the considered right covers the possibility of using any means of expressing thoughts — both traditional (oral, written, visual, etcetera), and modern-technical (Rabinovich and Havronyuk, 2004: 158-159).

One of the areas where the realization of such rights as freedom of thought and speech, free expression of their views and beliefs, information occurs is education. On the one hand, the exercise of the right to educa-

10 European Convention for the Protection of Human Rights and Fundamental Freedoms: Implementation in Ukraine (2006).

Esta obra está bajo una Licencia Creative Commons

Atribución-NoComercial-SinDerivar 4.0 Internacional, IIJ-UNAM.

Boletín Mexicano de Derecho Comparado, núm. 154, enero-abril de 2019, pp. 539-568. 
tion ensures that the person acquires the knowledge on the basis of which views, beliefs, worldview are formed, and attained communicative competences. On the other hand, it is not possible to obtain education without free expression of views and beliefs, ideas, concepts, free reception, use, dissemination of the information necessary for realization of the right to education by a person and a citizen. The right to freedom of thought and speech, free expression of their views and convictions, the right to information allow a person and a citizen to exercise the right to education, because they provide the process of knowledge transfer, acquiring of skills, abilities, life experience, and influence the culture of individual behavior. It is no coincidence that some of these rights are reflected in the educational legislation of Ukraine and a number of European countries. So, Article 53 of the Law of Ukraine "On Education" of September 5, 2017 guarantees learners access to information resources. Article 46 of the United (Organic) Law on the Universities of Spain of 21 December 2001 proclaims the right of students to "information about the university activity, the publicity of the university rules which govern the process of confirming students' knowledge of freedom of speech". According to Article 3 (Ley Orgánica 6/2001) of United (Organic) Law on Education Quality Improvement of Spain, dated December 9, 2013, parents have the right to receive information about the educational success of their children (Ley Orgánica 8/2013). The Framework Law on Higher Education of the Federal Republic of Germany of 19 January 1999 obliges higher education institutions to inform the public on the implementation of their assigned tasks. ${ }^{11}$

Under the right of information, we understand the possibility of free obtaining, use, dissemination, storage and protection of information necessary for the exercise of their rights, freedoms and legitimate interests. Extrapolating this into the educational sphere, we can say that the participants of the educational process have the following possibilities: to present educational questions to each other and receive answers to them; freely discuss topics and express their own views and beliefs on issues covered

11 Hochschulrahmengesetz in der Fassung der Bekanntmachung vom 19. Januar 1999 (BGBl. I S. 18), das zuletzt durch Artikel 2 des Gesetzes vom 12. April 2007 (BGBl. I S. 506) geändert worden ist (n. d.). 
by curricula; freely receive, store, use, distribute and protect educational information, etcetera.

So, between the rights: to education, freedom of thought and speech, free expression of views and beliefs, to the information, there is a close relationship. On the one hand, the right to education forms the views and beliefs of a person and citizen, and, on the other hand, their free expression, as well as obtaining, use, dissemination of information, ensure full realization of the right to education. Therefore, we believe that the rights: to freedom of thought and speech, free expression of views and beliefs, information, serve as original guarantees of the right to education.

\section{RELATIONSHIP BETWEEN THE RIGHT TO EDUCATION AND THE RIGHT TO WORK}

Given that the right to education and the right to work belong to one group of social and economic rights and interact closely with each other, there is a need to clarify the relationship between them.

The right to work was internationally recognized in Article 23 of the Universal Declaration of Human Rights, which states that everyone has the right to work, to fair and favorable conditions of work and protection from unemployment. ${ }^{12}$ In accordance with Part 1 of Article 6 of the International Covenant on Economic, Social and Cultural Rights, this right includes the possibility of earning a living for by work, which is freely chosen or freely agreed for (International Covenant on Civil and Political Rights, 1995). At the same time in Part 2 of Article 6 are outlineed steps that must be taken to fully implement the right to work - they include vocational education and training programs, ways and means to achieve productive employment.

The importance of obtaining education by children and its relationship with labor, which should not restrict the right to education or interfere with its implementation, is reflected in Part 1 of Article 32 of the Convention on the Rights of a Child. This document recognizes the right of a child to protection against economic exploitation and from perform-

12 The Universal Declaration of Human Rights, adopted and proclaimed by Resolution 217 A (III) of the General Assembly of the United Nations of December 10, 1948 (2008).

Esta obra está bajo una Licencia Creative Commons

Atribución-NoComercial-SinDerivar 4.0 Internacional, IIJ-UNAM.

Boletín Mexicano de Derecho Comparado, núm. 154, enero-abril de 2019, pp. 539-568. 
ing any work that may present a health hazard, to be an obstacle to his/ her education or to harm his/her health, physical, mental, spiritual, moral and social development. International standards in the field of the rights of the child recognize the priority of obtaining education by a child and connect the age of a person for employment with the age of completion of compulsory school education.

The right to work is guaranteed by the constitutions of Belarus (Article 42), Russia (Article 37), Germany (Article 12). In the Constitution of Spain (Article 35), it is proclaimed both a duty and a right. According to Article 43 of the Constitution of Ukraine everyone has the right to work, which includes a possibility of earning a living by work, which he freely chooses or freely agrees to. The State creates conditions for the full exercise of the right to work by citizens, guarantees equal opportunities in choosing an occupation and kind of employment, implements programs of vocational education, training and retraining of staff in accordance with public needs.

It is necessary to recognize that the level of education is one of the main factors of competitiveness of an employee in the labor market. This indicator is significant not only during employment, but also in reducing the number or staff of workers in connection with changes in the organization of production and labor (Bratasyuk, 1999). Under these conditions, workers with higher qualifications and labor productivity have a preferential right to remain at work. In addition, professional and business qualities of an employee, which should include the level of skills, is one of the factors determining the amount of wages.

Realization of the right to education is a necessary condition for the exercise of the right to work, especially when the law requires a diploma to obtain a certain qualification level before taking up a particular position. Despite the fact that education increases the chances of a person to work, choice of profession and occupation, establishment of decent working conditions and payment, yet the realities of life prove that the availability of education does not always guarantee a person the exercise of the right to work, as evidence of what is the presence of people with higher education among unemployed. Unemployed graduates of higher educational institutions, their lack of demand as specialists undermine the value of the right to education in society and at the same time testifies that the implementation of the latter without the right to work is not complete. 
After all, the level of employment can be regarded as a kind of a test for demand of those who exercise their right to education. In addition, the exercise of the right to work serves as an additional guarantee of the exercise of the right to continuous education through constant professional development and periodic training for workers. In this regard, the state's task is to improve a labor market by preserving existing ones and creating new jobs. Looking forward to solving this problem, we see balancing of labor supply and demand for it through the establishment of a social partnership between employers and educational institutions, and introduction of subsidies to employers when employing graduates.

Consequently, on the one hand, by providing a person with knowledge, skills, abilities, competence, the right to education serves as a means of satisfying the right to work. On the other hand, the capacity to implement the latter increases the value of education as a social phenomenon and, in general, the possibility of exercising the right to education.

\section{INTERACTION OF RIGHTS: TO EDUCATION AND SOCIAL PROTECTION}

There is a need to find out the relationship between the right to education and the right to social protection. This is conditioned, firstly, by their social essence, which requires significant efforts of the State to provide them; and secondly, by common purpose, which is aimed at the formation and development of a person and a citizen; thirdly, by the idea of "entering" the right to affordable and free education at the State and municipal educational institutions as an integral part of the right to social protection (Bolotina, 2005: 99). This testifies about the close connection between the designated rights and the need to study their interaction.

To understand the essence of the right to social protection, we will turn to the Universal Declaration of Human Rights, which proclaims the right of every person to social security and to exercise the rights necessary for the maintenance of his/her dignity and free development of a person in the economic, social and cultural fields through national efforts and international cooperation and in accordance with the structure and resourc- 
es of each State. ${ }^{13}$ Specific obligations of member states regarding social security are contained in Article 9 of the International Covenant on Economic, Social and Cultural Rights. In addition, we note that Article 13 of this document, addressed to the right to education, states that for the full implementation of the latter, a satisfactory system of scholarships should be established and the material conditions of the teaching staff should be constantly improved (International Covenant on Civil and Political Rights 1995). The right to social protection guarantees the constitutions of Belarus (Article 47), Russia (Article 39), Germany (Article 6), and Spain (Article 50). The right to social protection at the national level is proclaimed by Article 46 of the Constitution of Ukraine, which includes the right to provide citizens with full, partial or temporary disability, loss of breadwinner, unemployment due to independent of them circumstances, as well as in old age and in other cases stipulated by law.

Generally accepted scientific notion of "right to social protection" is absent. Moreover, there are differences in understanding of the relationship between the categories of "social protection" and "social security". Without going into discussion on this subject, we consider the right to social protection is

provided by the law, guaranteed by the state certain possibilities of a person to receive from the state, as well as other entities acting on the authority or permission of the state, under the conditions and in the manner provided by law, as well as the contract, material support, material support and social services in the event of social risks (Bolotina, 2005: 112-113).

Clarification of the essence of the right to social protection leads us to conclude that, despite the relationship between rights and their belonging to a social group, there is a significant difference between them - if everyone has the right to education, then the basis for realization of the right to social protection is social risks. They are "such events in a person's life, in which there is a danger of loss of material means to satisfy his/ her primary (basic) needs, necessary for preservation and reproduction of high-grade life as a member of human society" (Bolotina, 2005: 77).

13 (The Universal Declaration of Human Rights, adopted and proclaimed by Resolution 217 A (III) of the General Assembly of the United Nations of December 10, 1948 (2008). 
Apart from the right to social protection, a number of people would not be able to exercise their right to education at all. After all, it is precisely with the participation of the State and other persons authorized by it that the adverse circumstances of life, in which a person falls into, the trainee and the one who teaches, are offset.

The right to social protection actually "accompanies" the right to education. For example, in order to get an education, a trainee must come to an institution every day. Daily realization of the right to education becomes possible due to the establishment by a social state of privileged passenger transportation for persons who are studying. Particular importance is given to solving this problem for pupils living in rural areas, located at a considerable distance from school. Therefore, the legislation of Ukraine and European countries regulates the issue of providing students with the right to privileged or free travel to school. Currently, despite the post-industrial development of society, not every family is able to provide a child with adequate nutrition. Under conditions of malnutrition, it's impossible not only to exercise the right to education, but even to think about meeting other important needs, except for food. Therefore, from the point of view of the right to social protection, the State must assume minimization of such risks by organizing nutrition in educational institutions on concessional terms.

In any case, when there are social risks, the list of which can not be foreseen due to objective circumstances, the right to social protection must exercise its mission. This right guarantees participants of educational legal relationships the opportunity to receive from the State, as well as other entities authorized by it, material security, material support and social services in the event of social risks. Such measures allow people to exercise their right to education. That is, in the absence of the right to social protection, in some cases, the realization of the right to education is impossible. Thus, there is a close relationship between the rights analyzed, which is expressed in the fact that the right to social protection is a kind of guarantee for the right to education.

\section{CONCLUSIONS}

Thus, the right to education in the system of constitutional rights is one of the leading points, being the basis for the development of other Esta obra está bajo una Licencia Creative Commons Atribución-NoComercial-SinDerivar 4.0 Internacional, IIJ-UNAM.

Boletín Mexicano de Derecho Comparado, núm. 154, enero-abril de 2019, pp. 539-568. 
human rights. By such a criterion as the sphere of public relations, it belongs to the category of cultural rights. Since the right to education also satisfies social and economic needs, it can also be classified as a group of social and economic rights.

The relation between the right to education and other rights is expressed in the close connection between them and interdependence of one right to others. Realization of the right to education would be inferior without satisfaction of the right to dignity, freedom of creativity, thought and speech, free expression of views and beliefs, the right to information, free development of the individual. In its turn, the exercise of these rights would also be ineffective without the exercise of the right to education, which is a means of ensuring the majority of constitutional human rights.

\section{BIBLIOGRAPHY}

Alebastrova, I. A., 2010, "Social Rights: Constitutional Promises or Ghosts?", State and Law.

Beiter, Klaus Dieter, 2006, The Protection of the Right to Education by International Law, Boston, Martinus Nijhoff Publishers.

Bolotina, N. B., 2005, The Right to Social Protection: Establishment and Development in Ukraine, Kyiv.

BonyaK, V. O., 2005, Constitutional Right of a Person and Citizen to Education and Its Provision in Ukraine, Kyiv.

BratasyuK, M. G., 1999, "Human Dignity as a Source of European Human Rights Standards", Scientific Bulletin of the Kyiv National University of Internal Affairs, Kyiv, No. 3, 2010. Convention on the Rights of the Child.

Constitución Política de los Estados Unidos Mexicanos. Avalaible at: http://wrer.diputados.gob.mx/LeyesBiblio/pdf/1_150917.pdf.

"Declaration on the Right to Development Dated December 4", 1986. Avalaible at: http://zakon2.rada.gov.ua/laws/show/995_301.

Economic Encyclopedic Dictionary, 2005, Lviv, Ed. Mocherny.

Educational Legislation of Foreign Countries. Laws of Austria, Great Britain, Spain, China, Mexico, the Netherlands, France, 2003, Moscow, Education Legislation.

European Convention for the Protection of Human Rights and Fundamental Freedoms: Implementation in Ukraine, 2006, Kyiv. 
Esta revista forma parte del acervo de la Biblioteca Jurídica Virtual del Instituto de Investigaciones Jurídicas de la UNAM

French Code of Education, 2003. Avalaible at: Moscow, http: wrere. lexed.ru/ books.

Frolov, Y., 2005, "Economic Rights and Freedoms of a Person and a

Citizen in Ukraine", International Police Encyclopedia in 10 volumes.

Goncharenko, S. U., 2008, "Education", Encyclopedia of Education.

Great Dictionary of Contemporary Ukrainian Language, 2002, Kyiv-Irpin, Editor-in-Chief V. T. Busel.

"Hochschulrahmengesetz in Der Fassung Der Bekanntmachung Vom 19. Januar 1999 (BGBl. I S. 18), Das Zuletzt Durch Artikel 2 Des Gesetzes Vom 12. April 2007 (BGBl. I S. 506) Geändert Worden Ist”. Avalaible at: http://wrere.gesetze-im-internet.de/bundesrecht/hrg/gesamt.pdf.

"In Chernivtsi, a Teacher Who Beat a Pupil in a Classroom, Was Sentenced to One Year Imprisonment". Avalaible at: http://zik.ua/ua/ news/2010/02/05/215465.

"In Zaporozhye, a Teacher Broke the Nose to the 9th Grade". Avalaible at: http://tyzhden.ua/Neres/18542.

"International Covenant on Civil and Political Rights", 1995, In Optional Protocol to the International Covenant on Civil and Political Rights, Kyiv.

Jenis, M. et al., 1997, European Law in the Field of Human Rights: Sources and Practice of Application, Budapest, Kyiv.

Horbath, Jorge E. and Gracia, María Amalia, El derecho a la educación: un análisis a partir de la política educativa de las dos últimas décadas en México. Avalaible at: https://revistas.unimilitar.edu.co/index.php/ries/article/ view/1373/1164.

KalpinskayA, O. E., 2005, The Right to Education and the Mechanism of Its Realization in the System of the Ministry of Internal Affairs of Russia: Theoretical and Applied Aspect, St. Petersburg.

Karpachova, N. I., 2010, Status of Observance and Protection of the Rights of the Child in Ukraine.Special Report of the Commissioner for Human Rights of Verkhowna Rada of Ukraine, Kyiv, The 20th Anniversary of Ukraine's Ratification of the UN Convention on the Rights of the Child.

Kostetska, T. A., 2008, "The Right of a Person to Life and Respect for His Dignity", Constitutional Rights, Freedoms and Duties of a Person and a Citizen in Ukraine.

LisenKov, S. L., 2001, Cultural Law, Kyiv.

Maksimov, S. I., 2009, "Social Rights: To the Problem of Justification", Problems of Legality.

Esta obra está bajo una Licencia Creative Commons

Atribución-NoComercial-SinDerivar 4.0 Internacional, IIJ-UNAM.

Boletín Mexicano de Derecho Comparado, núm. 154, enero-abril de 2019, pp. 539-568. 
Malyarenko, T., 2010, "Human Right to Development in the Strategy of National Security Management of Ukraine", Efficiency of Public Administration.

Martynyuk, S. et al., 2001, "People's Economy", Economic Encyclopedia.

Matyusheva, T. N., 2008, "Educational Institutions in the Mechanism for the Implementation of the Constitutional Right to Education: Problems of Typology", Law and Education.

Milova, T. M., 2008, Constitutional Right of a Person and a Citizen to Freedom of Scientific Creativity in Ukraine, Kyiv.

Motakef, Mona, 2006, Das Menschenrecht Auf Bildung Und Der Schutz Vor Diskriminierung, Deutsches Institut für Menschenrechte.

NAZARCO, S. O., 2009, "The Impact of Education on Regional Human Development and Employment of the Population", Actual Problems of Economics.

OliINYK, A. Y., 2000, Constitutional and Legal Mechanism of Providing Basic Freedoms of a Person and a Citizen in Ukraine, Kyiv.

Pustovit, Z. M., 2003, "Social Rights of Citizens", Law Encyclopedia 5.

Rabinovich, P. M. and Havronyuk, M. I., 2004, Rights of a Person and a Citizen, Kyiv.

Rabinovich, P. M. and Pankevich, O., 2003, "Social Law: Some Issues of General Theory", Law of Ukraine.

RabinOvich, P. M., 2001, "Methodology of Legal Science", Law Encyclopedia.

Rabinovich, P. M., 2003, "The Science of the Philosophy of Law: To the Characterization of the Subject and Methodology", Problems of the Philosophy of Law.

"Right to Education Indicator Based on the 4 A Framework. Concept Paper, Prepared by Gauthier de Beco, Independent Consultant for The Right to Education Project", 2009. Avalaible at: http://wwrerighttoeducation.org/sites/r2e.gn.apc.org/files/Concept Paper.pdf.

Romanenko, K. M., 2008, Constitutional Right of a Citizen to Education in Ukraine: State and Development Trends, Ukraine, Zaporizhzhia.

Rybakova, V. V., 2005, Constitutional Right to General Education in the Russian Federation: Problems of Theory and Practice, Russia, Yekaterinburg.

Rybalka, V. V., 2010, "Honor and Dignity of Personalities of a Teacher and a Student as a Value Potential of Higher Education", Scientific 
Esta revista forma parte del acervo de la Biblioteca Jurídica Virtual del Instituto de Investigaciones Jurídicas de la UNAM

Bulletin of the Melitopol State Pedagogical University named after Bogdan Khmelnytsky.

Shemshuchenko, Y. and Milova, T., 2008, "Freedom of Scientific Creativity as a Constitutional Right of a Person and a Citizen", Bulletin of the National Academy of Sciences of Ukraine.

SkAKun, O. F., 2001, Theory of State and Law, Ukraine, Kharkiv.

Smirnova, V. M., 2006, Constitutional Right to Education and Guarantees of Its Realization in Non-State General Educational Institutions, Moscow.

SMIRNOVA, V. M., 2011, "Legal Regulation of Private Education under the Legislation of Foreign Countries: Private School - Libera, Non Privata?", Yearbook of Russian Educational Law.

"The Constitution of Ukraine, Adopted at the Fifth Session of the Verkhovna Rada of Ukraine on June 28, 1996”, 1996, Bulletin of the Verkhovna Rada of Ukraine.

"The Number of Children Who Do Not Attend School Is Increasing Again, Especially in Africa". Avalaible at: http://osvita.ua/school/ news/29917/print.

"The Universal Declaration of Human Rights, Adopted and Proclaimed by Resolution 217 A (III) of the General Assembly of the United Nations of December 10, 1948", 2008, Official Bulletin of Ukraine.

"Thüringer Schulgesetz (ThürSchulG) in Der Fassung Der Bekanntmachung", 2003. Avalaible at: http://wrwr.berlin.de/sen/bildung/rechtsvorschriften.

Tserkovna, A. O., 2003, Dignity and Honor in the Civil Law of Ukraine, Kyiv.

TsOmPlaK, K., 2012, "Human Dignity: Essence, Content and Preconditions of Existence", Public Law.

TyapkinA, I. V., 2009, Legal Mechanism of the Constitutional Right to Education in Secondary and Higher Vocational Education Institutions in Russia, Moscow.

Vdovichenko, S., Kampo, V., 2012, "The Right to Human Dignity: Ukrainian Theory and Practice in the Context of European Experience", Herald of the Constitutional Court of Ukraine.

ZURITA RIVERA, Úrsula, 2011, Los desafios del derecho a la educación en méxico a propósito de la participación social y la violencia escolar, México. Avalaible at: https://wwre.culturadelalegalidad.org.mx/recursos/Contenidos/Educacion/ documentos. 